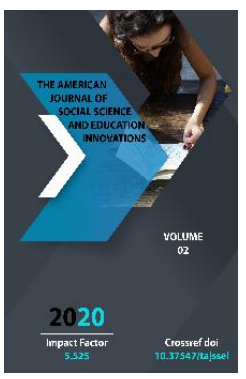

\title{
The Essence Of Effectiveness Of Family Buisness
}

\author{
Taylyaqova Feruza Sultanovna \\ Senior Lecturer, Department Of Humanities, Andijan Machine Building Institute, Andijan, \\ Uzbekistan
}

Journal Website:

http://usajournalshub.c

om/index,php/tajssei

Copyright: Original

content from this work

may be used under the

terms of the creative

commons attributes

4.0 licence.

\section{ABSTRACT}

The article provides a scientific analysis of the essence of family business, as an important aspect of economic development. The social functions and efficiency of family business are described on the basis of statistics.

\section{KEYWORDS}

Entrepreneur, family business, private entrepreneurship, business, salary, profit, pedocentrism, professionalism.

\section{INTRODUCTION}

The methodological basis of the analysis of small business and private entrepreneurship, including family entrepreneurship, is the theory of entrepreneurship, from a broader perspective, the theory of market economy. Given that the transition to a market economy in Uzbekistan is based on the "Uzbek model" founded by the First President Islam Karimov, it is clear that the methodological basis for the analysis of family business in the country is the Uzbek model. In other words, the formation and development of family business in Uzbekistan has in common with the formation and development of family business in the 
world, and at the same time has its own characteristics.

Theoretical analysis of the formation and development of family business in Uzbekistan is based on the theory of entrepreneurship. One of the founders of this theory is the English economist F. Cantilion. In his Essays on the Nature of Commerce, which he created in the mid-18th century, he introduced the concept of the "private entrepreneur" into the scientific community as a business entity. The play shows that a private entrepreneur is a business entity that is ready to take the risk of creating a new enterprise, a new economic idea, a new product, a new type of service.

According to the French economist J-B.Sey, an entrepreneur is a person who takes a risk to produce a product at his own expense and for his own benefit. Its main task is to gather information, relevant experience, link them to the factors of production, make appropriate decisions and organize the production process. According to Sey, the benefits of entrepreneurship consist of two parts:

1. "Industrial profits"; "Profit from capital". An entrepreneur can also benefit from intermediation because he is aware of things that other participants in the business process do not know.

Although Cantelion and Sey expressed valuable opinions about the entrepreneur, the logically complete theory in this area was created by the American economist and sociologist Y.Shumpeter. His main ideas about a private entrepreneur can be expressed in the following rules:

- The main function of the enterprise is to reform the production of new or refurbished old products, using new sources of raw materials, markets for raw materials and inventions and various other opportunities to explore new markets for the sale of products;

- The main content of entrepreneurial activity is the "new combination" of factors of production and behavior or the introduction of various regional innovations

- Entrepreneurship - a universal economic function of any social formation;

- The state of the economic and political environment is of particular importance for entrepreneurship;

The environment determines not only the ways of using "new combinations", but also the main types of business motivation.

Y. Schumpeter's views on entrepreneurship served as the basis for the institutionalevolutionary economic theory that began to develop in the first quarter of the twentieth century.

A number of founders of classical and neoclassical socio-economic schools also joined Schumpeter's views on entrepreneurship.

A. Marshall, the founder of the Cambridge School of Political Economy, pointed out the following functions of entrepreneurship:

- Connection of capital and labor;

- Development of the general plan of production;

- Control over goods and services;

- Sales of goods and services. In his opinion, entrepreneurship is a highly skilled labor in the current management of the enterprise.

Weber had linked Western entrepreneurship to Protestant ethics. The "entrepreneurial spirit" and the "burgher or civic spirit" were opposed by $M$. Zombard, the two main spiritual features of capitalism. By 
entrepreneurial spirit, he understood the institutionalized willingness to take risks, spiritual freedom, richness of ideas, will and perseverance, the ability to persuade people to buy the goods offered, the ability to gain their trust.

According to V. Zombard, an entrepreneur is an "invader", "organizer", "trader". These qualities are a reflection of the diligence, moderation, reckoning, and so on, peculiar to the bourgeoisie. He emphasizes that the main purpose of entrepreneurial activity is to strive for the prosperity of the business, the enterprise, and profit is a completely incomprehensible aspect, as it is subordinated to this goal and often serves to prosper. A businessman who just wants to make a profit can never be a real big entrepreneur.

F. Knight, the founder of the Chicago School of Economic Theory, focuses on the issue of uncertainty in the activities of entrepreneurs. Keynes, one of the great economists, also drew attention to this issue. In his view, the reason for the uncertainty is that the goal of economic activity is to achieve real or potential results, which are significantly different from the wages that can be obtained when the results are relatively long, and sometimes the duration is unknown. Entrepreneurs on the basis of this income, according to Knight, are the income paid to the manager for putting himself in an uncertain position by investing in a certain purpose. Knight pays special attention to features such as entrepreneurs 'ability to see intuitively in advance, their firm belief that their conclusions are correct, and their willingness to prove their conclusions even if they risk their capital.

Hayok Schumpeter, the founder of the New Austrian School of Economics, agrees with many of his ideas. For him, the highest value of a market economy is individual freedom. This freedom excludes the individual from being subject to the will of other people, but he is subject to the laws of civil society. According to Khayok's theory, each person's knowledge is unitary, but the use of this knowledge requires the direct and active participation of the individual. Uncertainty about the state of the market provides an opportunity to "open a window to the future." The driving force behind the search for new opportunities is the entrepreneur. Because he seeks to use his unique knowledge in a market situation and thus win the competition and make a big profit.

Institutional-evolutionary theory creates the opportunity for a comprehensive study of various aspects of the economic life of society. This theory mastered many aspects of biology, cybernetics, systems theory, and the methodology of other sciences and adapted them to the analysis of economic life.

\section{MAIN PART}

The term "family business" consists of two concepts: "family" and "entrepreneurship". While both of these concepts seem understandable, a content analysis of existing literature shows that different authors give them different meanings. One of the reasons for this is that with the passage of time, each of them is undergoing certain changes. With this in mind, we found it necessary to dwell on the changes that have taken place over the past 15-20 years, including changes in the approaches to the family and entrepreneurship in the context of the changes that have taken place in our country. The concept of "family" originated in ancient times, several thousand years ago, and it has undergone a number of significant changes. 
Since it is not directly related to the subject under study, we will not dwell on matriarchy and patriarchy, polygamy and monogamy, which are characteristic of the early stages of family formation. We do not even consider it necessary to dwell on the structure and functions of the national family in this context. Because these topics are widely covered by foreign and domestic scientists.

Even in the last 20-30 years, the family has undergone a number of changes. Before talking about these changes, it is necessary to dwell, albeit briefly, on family types and functions.

In the literature on sociology and philosophy, the family is interpreted as the smallest part of society - the cell. As a cell, it reflects the characteristics of the whole-society and itself has a significant impact on the essence and development of society.

The basis of the family is the marital relationship. Couples' relationships are based primarily on the values and stereotypes that exist in society. This relationship is also strongly influenced by the motives behind marriage. The influence of the economic base of society on family relations is also realized through motives. The family is a small social group formed on the basis of marital, parental, kinship relations and forms a single family activity.

Although the basis of a family is a couple, there are also families that consist of one parent. In nuclear families, parents and children live together. In extended families, in addition to the couple and their children, there may be grandparents. In the family at the beginning of the XXI century, along with the influence of family relations of past centuries, the buds of future families are also visible.

The family performs a number of functions. The fulfillment of these functions ensures the existence not only of the family but also of society. The most important family functions are: reproductive, educational, economic and others.

In the process of the gradual development of society, all the functions of the family undergo certain changes. Reproductive function, which is related to a couple's physiological characteristics as individuals, also undergoes certain changes under the influence of social development. This function, which has ensured the existence of society since ancient times, is undergoing certain changes. In the social situation that emerged in the late twentieth and early twenty-first centuries, there are certain incentives and at the same time obstacles to the fulfillment of the reproductive function.

The social and economic situation in different countries also affects the age of marriage. For example, the age of marriage in European countries is 28 years, while in Japan it is $30-33$ years. The average age of marriage in the Central Asian republics is 20-22 years.

Early marriage prevents young people from getting an education and a profession. Especially after the birth of a child, the couple has certain difficulties in studying at universities, in finding a profession. As a result, young people who get married early are deprived of the opportunity to hold highranking specialties, and therefore to hold highranking positions. Such situations affect the stability of the young family, a certain part of such families are separated. 
Another of the most important functions of the family is the educational function. In fulfilling this function, no institution in society can replace the family. Nowadays, the family's ability to perform its educational function is declining. One of the main reasons for this is that in most families, both husband and wife work. This limits the time factor in the performance of the educational functions of the family. As a result, children in certain families are left to fend for themselves while their parents are at work. Such a situation inevitably affects the learning and upbringing of children.

From the point of view of modern sociology, families are divided into several types according to their educational function:

- Pedocentrism. Such families are characterized by excessive attention to the child. Especially when the child is one, both the father and the mother and the grandparents try to fulfill all his wishes. Usually such children are formed selfish. They are unable to overcome the difficulties in life:

- Professionalism. In this type of family, the parents leave the child's upbringing to special institutions: kindergartens, schools and educators. Among the children raised in such families, there will be emotionally cold people in the future. They have almost no respect for parents, adults;

- Pragmatism. In families of this type, the main purpose of upbringing will be to form such qualities as how to live, how to get material benefits.

- At present, in our country there are all three types of families listed above. However, the existing national values in our country, the traditions of respect for adults and parents ensure that children are formed on the basis of national values. At the same time, it should not be forgotten that the opportunities for the formation of individualism are expanding under the influence of developing market relations.

The economic function of the family is manifested in many forms. This function is reflected in the management of the household, family budget management, organization of consumption and recreation. The role of the family in the organization of consumption and domestic life is very important. In the process of consumption, human material needs are not only met, but also formed. In this process, certain household traditions are formed and supported.

The productive function of the family, which had existed for many centuries, fell to a minimum during the Soviet regime. Most of the families that existed under this system were almost never engaged in production. This does not mean that family members were not involved in the production at all. The family members worked separately in factories, in the service sector, in agriculture. But this is not a family production.

Under the pressure of the Soviet regime, the qualities of family entrepreneurship fell into disrepair. Family business, which had been encouraged for centuries, was suppressed in the system of administrative command. The reason for this was that family business was incompatible with the ideology of the Soviet system, which, in communist terms, was "characteristic of the petty bourgeoisie." By the time of independence, the revival of private property had paved the way for the development of family business. But for more than 70 years during the Soviet era, family business traditions were much forgotten. Therefore, in the beginning it was very 
difficult to involve people in family business. The negative stereotypes of the Soviet regime are still manifesting themselves to some extent today.

The development of family business in independent Uzbekistan, which is undergoing radical socio-economic reforms, plays an important role in solving a number of social problems. One of such problems is the social protection of low-income families, raising their living standards. One of the most promising ways to solve such a problem is to develop family business. A number of resolutions and decrees of the First President of the country I.Karimov, resolutions of the Cabinet of Ministers emphasize that family business is an important tool in improving the material wellbeing of families. The term "low-income family" refers to families who have difficulty meeting their minimum needs.

The World Bank estimates that the number of low-income and poor people in the world is 2.5 to 3 billion. Families with a daily per capita income of less than $\$ 2$ are considered poor. Families that spend less than a dollar per capita per day are considered poor.

Due to the fact that one of the main principles of the world-renowned "Uzbek model" is strong social protection, the number of lowincome families in our country is declining every year. While the main role in the social protection of low-income families today is played by funds allocated from the state budget and by business structures, family business plays an important strategic role in fulfilling this important social function. Family business is increasingly contributing to the country's economic growth and national wellbeing. The development of this institution also means that the number of low-income families is declining.
Entrepreneurship is a multifaceted phenomenon that covers almost all areas of social life: from the social and cultural spheres to the economic sphere.

According to world statistics, $70 \%$ of all businesses in the world are family businesses. In the East, the share of family business is close to $90 \%$.

This type of entrepreneurship plays a vital role in supporting the country's economy by providing employment. In Uzbekistan, at the beginning of 2016, 90\% of economic entities were small businesses and family businesses. The products and services produced at these enterprises accounted for about $57 \%$ of GDP.

It is necessary to recognize that the important measures taken in the development of family business in our country, along with the recognition of the created solid legal and regulatory framework, also have certain difficulties and obstacles. One of such obstacles is the fact that corruption in our country has not yet been completely eliminated, bureaucracy and greed. The development of civil society institutions has not yet reached a very high level, and the existing difficulties in the implementation of social partnership are among such obstacles. There are also barriers to human psychology, which are mainly related to the complications in the human mind of the administrativecommand system.

\section{CONCLUSION}

Family business is also characterized by its flexibility compared to other forms of management, rapid response to changes in the external environment and the ability to change their activities in accordance with them. These features are important in stabilizing the economic development and 
growth of our country. As in many countries around the world, Uzbekistan does not yet have accurate statistics on the share of family business in small and medium-sized businesses. In order to determine the share of family businesses in the structure of small and medium-sized businesses, it is necessary to determine which enterprises and entrepreneurs are included in the concept of "family business".

Our observations and interviews with entrepreneurs show that today family business has a significant share in the structure of private entrepreneurship.

\section{REFERENCES}

1. Abdullaev Yo. Basics of small business and entrepreneurship, 100 answers to 100 questions. Tashkent, "Labor", 2002

2. Abalkin L. The system of values in Russian economic thought (About the book "Russian economists (XIX beginning. XX centuries") Problems of Economics. 1998. No. 9

3. Algin A. P. Risk in entrepreneurship. SPb., 2002.

4. Bezgodov A.A. Essays on the Sociology of Entrepreneurship. Moscow: Progress, 2009.

5. Begmatov A, Incentives: Essence and Action, Tashkent "Fan" 1990

6. Bakshtanovsky V.I., Solomonov Yu.V. Entrepreneurship Ethics Vesti RAN, M., 2013. 